\title{
Effects of temperature on the heterogeneous oxidation of sulfur dioxide by ozone on calcium carbonate
}

\author{
L. Y. Wu, S. R. Tong, W. G. Wang, and M. F. Ge \\ Beijing National Laboratory for Molecular Sciences (BNLMS), State Key Laboratory for Structural Chemistry of Unstable \\ and Stable Species, Institute of Chemistry, Chinese Academy of Sciences, 100190, Beijing, China
}

Received: 17 January 2011 - Published in Atmos. Chem. Phys. Discuss.: 31 January 2011

Revised: 5 July 2011 - Accepted: 7 July 2011 - Published: 12 July 2011

\begin{abstract}
The heterogeneous oxidation of sulfur dioxide by ozone on $\mathrm{CaCO}_{3}$ was studied as a function of temperature $(230$ to $298 \mathrm{~K})$ at ambient pressure. Oxidation reactions were followed in real time using diffuse reflectance infrared Fourier transform spectrometry (DRIFTS) to obtain kinetic and mechanistic data. From the analysis of the spectral features, the formation of sulfate was identified on the surface in the presence of $\mathrm{O}_{3}$ and $\mathrm{SO}_{2}$ at different temperatures from 230 to $298 \mathrm{~K}$. The results showed that the heterogeneous oxidation and the rate of sulfate formation were sensitive to temperature. An interesting stage-transition region was observed at temperatures ranging from 230 to $257 \mathrm{~K}$, but it became ambiguous gradually above $257 \mathrm{~K}$. The reactive uptake coefficients at different temperatures from 230 to $298 \mathrm{~K}$ were acquired for the first time, which can be used directly in atmospheric chemistry modeling studies to predict the formation of secondary sulfate aerosol in the troposphere. Furthermore, the rate of sulfate formation had a turning point at about $250 \mathrm{~K}$. The sulfate concentration at $250 \mathrm{~K}$ was about twice as large as that at $298 \mathrm{~K}$. The rate of sulfate formation increased with decreasing temperature at temperatures above $250 \mathrm{~K}$, while there is a contrary temperature effect at temperatures below $250 \mathrm{~K}$. The activation energy for heterogeneous oxidation at temperatures from $245 \mathrm{~K}$ to $230 \mathrm{~K}$ was determined to be $14.63 \pm 0.20 \mathrm{~kJ} \mathrm{~mol}^{-1}$. A mechanism for the temperature dependence was proposed and the atmospheric implications were discussed.
\end{abstract}

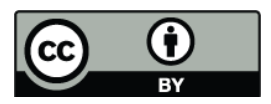

Correspondence to: M. F. Ge (gemaofa@iccas.ac.cn)

\section{Introduction}

Mineral aerosol is an important component of airborne particulate matter (PM). Emitted into the atmosphere predominantly from arid and semiarid regions at a rate of 1000 $3000 \mathrm{Tg}$ per year (Harrison et al., 2001; Dentener et al., 1996), it has been by mass one of the largest sources to the global budget of PM (Rossi, 2003). Mineral aerosol may be transported over thousands of kilometers (Prospero, 1999) and therefore found far away from their sources resulting in a global distribution of this kind of atmospheric aerosols (Husar et al., 2001). Even at altitudes of 10 to $12 \mathrm{~km}$, up to 500 part per trillion (ppt) of mineral ions (including $\mathrm{Ca}^{2+}$ $\mathrm{Mg}^{2+}, \mathrm{Na}^{+}$and so on) can be found in aerosol samples (Tabazadeh et al., 1998; Talbot et al., 1998; Cavalieri et al., 2010), indicating that these particles are also transported into the upper troposphere. During this process, mineral aerosol with atmospheric lifetimes of weeks (Prospero, 1999) plays a central role in global geochemical cycles as well as in climate change (Usher et al., 2003). It could affect the Earth's temperature either directly, by scattering and absorbing radiation ( $\mathrm{Li}$ et al., 1996; Bauer et al., 2007), or indirectly, by serving as cloud condensation nuclei (Cziczo et al., 2004; Koehler et al., 2010). In addition, mineral aerosol provides reactive sites for condensation and surface-mediated heterogeneous reactions with atmospheric trace gases and thus acts as sink or source for various atmospheric chemical species (Wagner et al., 2008). Recent atmospheric chemistry modeling studies (Dentener et al., 1996; Jacob, 2000; Zhang and Carmichael, 1999) have predicted that mineral aerosol can alter the chemical balance of the atmosphere through heterogeneous reactions.

Sulfur dioxide is one of the important atmospheric trace gases that can react with mineral aerosol (Usher and Grassian, 2001; Zhang et al., 2006; Li and Han, 2010). As a

Published by Copernicus Publications on behalf of the European Geosciences Union. 
well-known deleterious anthropogenic pollutant in the atmosphere, $\mathrm{SO}_{2}$ is released to the troposphere by fossil fuel combustion, volcanic emissions, oxidation of DMS, and other sulfur compounds of biogenic origin (Seinfeld, 1998). The $\mathrm{SO}_{2}$ concentration is about 50 to $100 \mathrm{ppt}$ in the lower stratosphere, $50 \mathrm{ppt}$ in the free troposphere, and as high as $160 \mathrm{ppt}$ in North American clean continental air (Seinfeld, 1998). It is estimated that nearly half of the global sulfur dioxide emissions are converted to particulate sulfate (Levin et al., 1996; Adams et al., 2005; Crowley et al., 2010). It is critical to understand the formation of sulfate particles in the troposphere because of their health effects and their direct and indirect effects on radiative forcing, and hence on climate (Laskin et al., 2003; Bauer et al., 2007).

There have been a number of atmospheric chemistry models applied to predict the formation of sulfate aerosols on a global scale (Langner and Rodhe, 1991; Pham et al., 1995; Kasibhatla et al., 1997), and the results revealed a systematic tendency of the modeling studies to overestimate $\mathrm{SO}_{2}$ concentrations and underestimate sulfate concentrations (Kasibhatla et al., 1997). Two well-known routes for $\mathrm{SO}_{2}$ oxidation to sulfate are via gaseous oxidation by $\mathrm{OH}$ radical (Seinfeld, 1998) and aqueous oxidation in cloud or fog droplets (Rattigan et al., 2000; Botha et al., 1994). But these two mechanisms are not enough to bridge the gap between field and modeling studies (Luria and Sievering, 1991). Recently, field measurements have found that most of the global mineral aerosol surface was coated with sulfate (Zhang et al., 2000; Zhuang et al., 1999). There is a correlation between particulate sulfate and mineral aerosol (Zhuang et al., 1992; Nishikawa et al., 1991) and such a correlation could be caused by surface reactions converting $\mathrm{SO}_{2}$ to $\mathrm{SO}_{4}^{2-}$ (Xiao et al., 1997; Song and Carmichael, 1999). Thus, the heterogeneous oxidation of $\mathrm{SO}_{2}$ to sulfate on mineral aerosol has received more and more attention in recent years (Dentener et al., 1996; Kasibhatla et al., 1997; Usher et al., 2003). A number of different substrates such as Saharan dust (Ullerstam et al., 2002), China loess (Usher et al., 2002), and some metal oxides (Goodman et al., 2001; Usher et al., 2002; AlHosney and Grassian, 2005; Li et al., 2006; Fu et al., 2007; Baltrusaitis et al., 2007; Ge et al., 2009; Fu et al., 2009) were used to study the kinetics and mechanisms of heterogeneous $\mathrm{SO}_{2}$ oxidation to sulfate. Particle properties (e.g., particle composition and size distributions), the reactive uptake coefficients, and mechanisms were considered in these studies. It is found that atmospheric conditions such as temperature, relative humidity and light irradiation play an important role in sulfate formation. To our knowledge, however, most of previous work was performed at room temperature. There is no direct study of the heterogeneous oxidation of $\mathrm{SO}_{2}$ on mineral dust at temperatures less than $298 \mathrm{~K}$.

The experimental determination of rate constants for important atmospheric reactions and how these rate constants vary with temperature remain a crucially important part of atmospheric science (Smith, 2003). Moreover, the seasonal variation of the sulfate burden can have a significant effect on the direct radiative forcing of sulfate aerosols (Shaw and Paur, 1983; Feichter et al., 1996). Thus it is important to explore sulfate formation as a function of seasonal temperature.

Calcium carbonate is an important and ubiquitous mineral in biological and geochemical systems (Al-Hosney and Grassian, 2004). In addition to influencing the global $\mathrm{CO}_{2}$ budget (Ridgwell and Zeebe, 2005), calcium carbonate is a reactive component of mineral aerosol in the troposphere and heterogeneous reactions of trace gases with carbonates can alter the chemical balance of the atmosphere (Hanisch and Crowley, 2001; Goudie and Middleton, 2001; Al-Hosney and Grassian, 2004; Laskin et al., 2005). In coal-burning power plants, $75-98 \%$ of the $\mathrm{SO}_{2}$ generated by combustion is removed by reaction with wet or dry limestone, which is predominantly composed of $\mathrm{CaCO}_{3}$ (Srivastava and Jozewicz, 2001).

On the basis of above reasons, the influence of temperature on the heterogeneous oxidation of $\mathrm{SO}_{2}$ by $\mathrm{O}_{3}$ on $\mathrm{CaCO}_{3}$ particles was investigated. Using diffuse reflectance infrared Fourier transform spectroscopy (DRIFTS), a series of reactive uptake coefficients for the heterogeneous oxidation of $\mathrm{SO}_{2}$ by $\mathrm{O}_{3}$ on the surface of $\mathrm{CaCO}_{3}$ particles at different temperatures was obtained. The reactive uptake coefficients at different temperatures will supply the basic data for atmospheric chemistry modeling studies. Moreover, the mechanism of the temperature dependence of rate constants was also discussed. The results are helpful for the further understanding of the seasonal variation of secondary sulfate aerosols as well as the spatial distribution of activity for the heterogeneous oxidation of $\mathrm{SO}_{2}$ on mineral dust particles in the troposphere.

\section{Experimental}

\subsection{Chemicals}

Commercially available $\mathrm{CaCO}_{3}$ particles were purchased from Alfa Aesar (with a stated purity of $99.5 \%$ ). The Brunauer-Emmett-Teller (BET) surface area of the particles was measured to be $1.35 \mathrm{~m}^{2} \mathrm{~g}^{-1}$ (Autosorb-1-MP automatic equipment (Quanta Chrome Instrument Co.)). $\mathrm{SO}_{2}(99.9 \%$, Beijing Huayuan Gas Chemical industry Co., Ltd.) was diluted and mixed with $\mathrm{N}_{2}(>99.999 \%$, Beijing Tailong Electronics Co., Ltd) before used. $\mathrm{O}_{2}(>99.998 \%$, Orient Center Gas Science \& Technology Co., Ltd.) was used to simulate the ambient air. Ultrapure water with resistivity of $18.2 \mathrm{M} \Omega \mathrm{cm}$ was purified by the Thermo Scientific Barnstead Easypure II systems (Model UF).

Ozone was generated by irradiating a dry flow of pure $\mathrm{O}_{2}$ with an ultraviolet lamp (Heraeus Ltd., ZSZ-8). The ozone concentrations in our experiments ranged from $2.8 \times 10^{14}$ molecules $\mathrm{cm}^{-3}$ to $7.4 \times 10^{14}$ molecules $\mathrm{cm}^{-3}$. The ozone concentration was determined by an ozone 
analyzer (Model 49i, Thermo Electron Corporation, UV Photometric technology). Before each experiment, the $\mathrm{O}_{3} / \mathrm{O}_{2}$ mixture was passed through the lamp compartment for $1 \mathrm{~h}$ to ensure that the ozone concentration was stable.

\subsection{Gas supply system}

The gas supply system was composed of four inlet lines which were made of Teflon tubing. The first line supplied diluted $\mathrm{SO}_{2}$ mixed with $\mathrm{N}_{2}$, and the concentration was $4.9 \times 10^{14}$ molecules $\mathrm{cm}^{-3}$; the second one provided a mixture of ozone and oxygen; the third line provided $\mathrm{O}_{2}$ for simulating the ambient air; and the fourth line was used to provide additional nitrogen gas for dilution. All gases were mixed together before entering the reactor chamber, resulting in a total flow of $400 \mathrm{sccm}$ synthetic air $\left(21 \% \mathrm{O}_{2}\right.$ and $\left.79 \% \mathrm{~N}_{2}\right) . \mathrm{N}_{2}$ and $\mathrm{O}_{2}$ were dehumidified by silica gel and molecular sieve before flowing into the system, and the relative humidity $(\mathrm{RH})$ was less than $1 \%$. The $\mathrm{SO}_{2}$ was diluted by $\mathrm{N}_{2}$ in a glass bottle and the partial pressure was monitored by absolute pressure transducer (MKS 627B range 0 to 1000 torr). Mass flow controllers (Beijing Sevenstar electronics Co., Ltd.) were used to adjust the flux of diluted $\mathrm{SO}_{2}$ and $\mathrm{N}_{2}$ to the desired concentration. The $\mathrm{O}_{3}$ concentration in the mixture was controlled by varying the flux of oxygen that was exposed to UV light. The reactant flow was forced to pass through the $\mathrm{CaCO}_{3}$ particles in the DRIFTS reactor. Average residence time of gases inside the DRIFTS cell was approximately $2.5 \mathrm{~s}$.

\subsection{Experimental methods}

Diffuse reflectance infrared Fourier transform spectroscopy (DRIFTS) has been used successfully for the analysis of solids, and it has applied extensively to study the kinetics and mechanisms of the heterogeneous chemistry on particle surfaces (Vogt and Finlayson-Pitts, 1994; Shaka et al., 2007; Li et al., 2006; Finlayson-Pitts, 2000). The advantage of DRIFTS is that it can be used to measure the reaction products in situ without interrupting the reaction processes (Finlayson-Pitts, 2000). DRIFTS can provide mechanistic details not available through other methods and kinetic data can also be obtained (Vogt and Finlayson-Pitts, 1994). It has also been possible to determine the reactive uptake coefficient.

A Nicolet FTIR Spectrometer 6700 equipped with a liquid-nitrogen-cooled narrow band mercury-cadmiumtelluride (MCT) detector and the Praying Mantis accessory (Model DRP, Harrick Scientific Corp.) was applied to record in situ DRIFTS spectra in the spectral range from 4000 to $650 \mathrm{~cm}^{-1}$. The low temperature reaction chamber (Model CHC-CHA-3, Harrick Scientific Corp.) was used in this study. This reaction chamber is designed for operation from $-150^{\circ} \mathrm{C}$ up to $600^{\circ} \mathrm{C}$ under vacuum. The temperature of the sample cup could be measured by a thermocouple lo- cated directly underneath. The temperature of the sample is controlled by counteracting liquid-nitrogen cooling with a resistive heating using an automatic temperature controller (ATC-024-2, Harrick Scientific Corp.). The sample cup is thermally isolated from the outer chamber wall. To prevent the $\mathrm{ZnSe}$ windows from frosting, a circulating water jacket was used to maintain the temperature of the outer surface of the chamber and windows at room temperature during low temperature operation.

To obtain a reproducible packing of the DRIFTS sampling cup, the $\mathrm{CaCO}_{3}$ powder (about $60 \mathrm{mg}$ ) was placed in the stainless steel cup (10 $\mathrm{mm}$ diameter, $0.5 \mathrm{~mm}$ depth) and compressed in order to form a solid pellet. $\mathrm{SO}_{2}$ and $\mathrm{O}_{3}$ with specific concentration in the dry synthetic air were then introduced into the reaction chamber and forced through the powder. The experimental conditions were controlled at ambient pressure under dry synthetic air at temperatures from 230 to $298 \mathrm{~K}$. In order to avoid a temperature difference between the sample holder and the solid sample, the system was thermostabilized for at least $1 \mathrm{~h}$ before each experiment. During the whole experimental procedure, the temperature uncertainty was $\pm 1 \mathrm{~K}$.

A typical experiment at each temperature lasted $200 \mathrm{~min}$. The spectra were recorded at a resolution of $4 \mathrm{~cm}^{-1}$, and 100 scans were usually averaged for each spectrum corresponding to a time resolution of $40 \mathrm{~s}$. All the spectral data were automatically collected by the Series program in OMINC software (Nicolet Corp.) in the experimental time. Simultaneously, the integrated absorbance of selected spectral features was obtained.

The products formed on $\mathrm{CaCO}_{3}$ surface were analyzed by ion chromatography after reaction. The reacted particles were sonicated for $20 \mathrm{~min}$ in $1.5 \mathrm{ml}$ of ultrapure water. The leaching water contained $1 \%$ formaldehyde as a preservative to enable the analysis of sulfite as well as sulfate. The filtered solution was analyzed using a Dionex ICS 900 system, which was equipped with a Dionex AS 14A analytical column and a conductivity detector (DS5).

\section{Results and discussion}

In order to explore the dependence of the rate constant on temperature for the oxidation of $\mathrm{SO}_{2}$, the following aspects must be investigated. First, the products formed in the reaction at different temperatures must be identified. Second, how did the parameters of kinetics vary with temperature.

\subsection{Observed products}

Prior to initiation of the experiments, the Teflon tube and the chamber were washed at least three times and then evacuated under high vacuum overnight to make sure that the whole gas supply system and the chamber were clean. An ultrapure sample was in situ pretreated by heating in synthetic air 


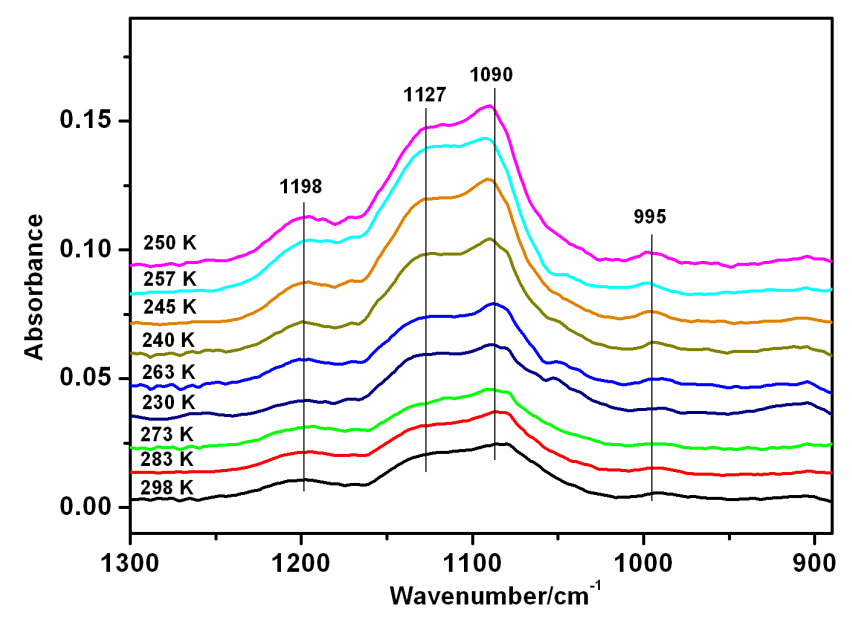

Fig. 1. In situ DRIFTS spectra (absorbance units) of surface products when $\mathrm{CaCO}_{3}$ particles were exposed simultaneously to $\mathrm{SO}_{2}$ $\left(4.9 \times 10^{14}\right.$ molecules $\left.\mathrm{cm}^{-3}\right)$ and $\mathrm{O}_{3}\left(4.9 \times 10^{14}\right.$ molecules $\left.\mathrm{cm}^{-3}\right)$ for $200 \mathrm{~min}$ at different temperatures under dry conditions $(\mathrm{RH}<1 \%)$. The spectra were ordered by increasing sulfate intensity.

at $573 \mathrm{~K}$ for $3 \mathrm{~h}$ before an experiment. This treatment can also remove surface-adsorbed substances such as adsorbed water from the surface (Koretsky et al., 1997; Börensen et al., 2000). After the pretreated sample was cooled to the desired experimental temperature, a backgroud spectrum of the unreacted sample in the reaction chamber was collected. Spectra of surface products were then collected and shown as positive bands. When $\mathrm{CaCO}_{3}$ particles were exposed simultaneously to $\mathrm{SO}_{2}\left(4.9 \times 10^{14}\right.$ molecules $\left.\mathrm{cm}^{-3}\right)$ and $\mathrm{O}_{3}$ $\left(4.9 \times 10^{14}\right.$ molecules $\left.\mathrm{cm}^{-3}\right)$ for $200 \mathrm{~min}$ at different temperatures under dry conditions $(\mathrm{RH}<1 \%)$, four new peaks were observed at 1198,1127,1090, and $995 \mathrm{~cm}^{-1}$, as shown in Fig. 1. The frequency cutoff below $883 \mathrm{~cm}^{-1}$ and above $1300 \mathrm{~cm}^{-1}$ was due to the strong absorption of the $\mathrm{CaCO}_{3}$ substrate $\left(878 \mathrm{~cm}^{-1}, 1795 \mathrm{~cm}^{-1}\right)$ and the water vapor interference $\left(1300 \mathrm{~cm}^{-1}\right.$ to $\left.2000 \mathrm{~cm}^{-1}\right)$ that existed in the environment outside of the DRIFTS chamber. Assignments of the absorbance peaks were facilitated by examination of spectra in the literature that involved the reactions of $\mathrm{SO}_{2}$ on mineral surfaces (Martin et al., 1987; Steger and Schmidt, 1964; Peak et al., 1999; Li et al., 2006). These new peaks were assigned to the stretching motion of adsorbed sulfate $\left(\mathrm{SO}_{4}^{2-}\right)$ on the surface. With the FTIR technique, there are two infrared sulfate vibrations that are accessible to spectroscopic investigation in the mid-infrared region. They are the nondegenerate symmetric stretching $v_{1}$ and the triply degenerate asymmetric stretching $v_{3}$ bands (Peak et al., 1999). When the heterogeneous oxidation of $\mathrm{SO}_{2}$ on the surface of $\mathrm{CaCO}_{3}$ occured, the $v_{1}$ band was weakly active and appeared at $995 \mathrm{~cm}^{-1}$. The $v_{3}$ band splited into three peaks, 1198 , 1127 , and $1090 \mathrm{~cm}^{-1}$, repectively. The formation of sulfate on $\mathrm{CaCO}_{3}$ was also confirmed by ion chromatography (IC).

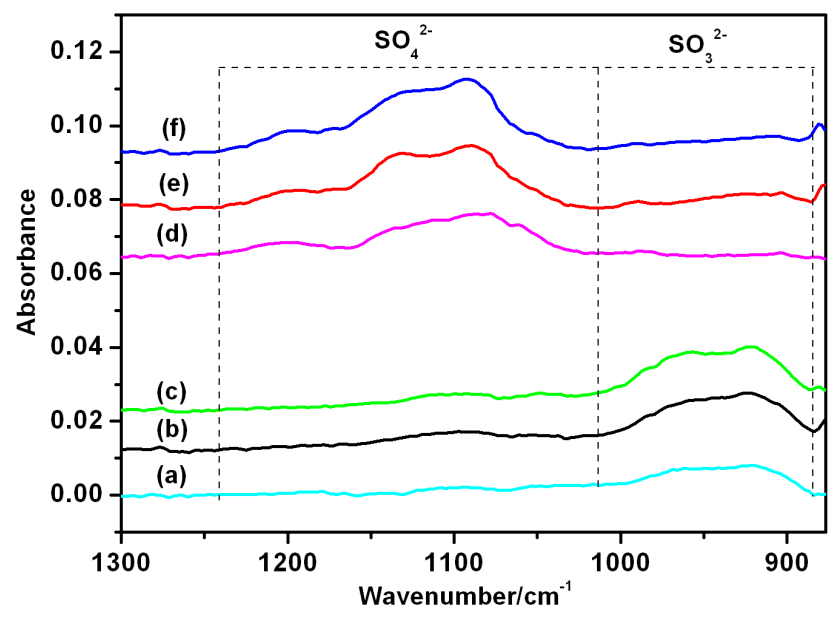

Fig. 2. In situ DRIFTS spectra of surface products when $\mathrm{CaCO}_{3}$ particles were exposed sequentially to $\mathrm{SO}_{2}\left(4.9 \times 10^{14}\right.$ molecules $\left.\mathrm{cm}^{-3}\right)$ and $\mathrm{O}_{3}\left(4.9 \times 10^{14}\right.$ molecules $\left.\mathrm{cm}^{-3}\right)$. (a), (b), (c) showed the product spectra when the adsorption rate becomes stable after addition of $\mathrm{SO}_{2}$ at $298 \mathrm{~K}, 263 \mathrm{~K}$ and $250 \mathrm{~K}$, respectively. (d), (e), (f) show the product spectra when the $\mathrm{SO}_{2}$ flow was cut off, and $\mathrm{O}_{3}$ was introduced into the reaction system for $60 \mathrm{~min}$ at $298 \mathrm{~K}$, $263 \mathrm{~K}$ and $250 \mathrm{~K}$, respectively.

The infrared spectrum of sulfate depends on its symmetry, while the symmetry of the adsorbed sulfate changes depending on whether it is monodentate or bidentate (Fu et al., 2007). In case of monodentate surface structure, sulfate adsorbs to the mineral surface through one oxygen atom, resulting in $\mathrm{C}_{3 v}$ symmetry. Thus the $v_{1}$ band becomes active at about $975 \mathrm{~cm}^{-1}$, and the $\nu_{3}$ band splits into two peaks which are present above $1000 \mathrm{~cm}^{-1}$ (Hug, 1997). If sulfate is bound to the surface through two oxygen atoms, forming a bidentate surface sulfato-metal complex, the symmetry of the sulfate is lowered to $\mathrm{C}_{2 v}$ (Rubasinghege et al., 2010). For this symmetry, the $\nu_{3}$ band splits into three peaks between 1050 and $1250 \mathrm{~cm}^{-1}$, while the $v_{1}$ band is shifted to about $1000 \mathrm{~cm}^{-1}$ (Peak et al., 1999; Martin et al., 1987). According to the peak splitting information provided by Fig. 1, the bidentate structure of sulfate on $\mathrm{CaCO}_{3}$ was proposed at temperatures from 230 to $298 \mathrm{~K}$.

To probe the details of the $\mathrm{SO}_{2}$ surface oxidation by $\mathrm{O}_{3}$ on the surface of $\mathrm{CaCO}_{3}$, several sequential exposure experiments were designed in this study. The experiments in which three temperatures were chosen included two steps, namely the sequential exposure to $\mathrm{SO}_{2}$ and $\mathrm{O}_{3}$. In the first experiment, $\mathrm{SO}_{2}$ was introduced to the flow system alone with dry synthetic air $(\mathrm{RH}<1 \%)$. The absorption bands present in the spectra shown in Fig. 2, curve a, b, and c can be assigned with the aid of previous infrared studies of $\mathrm{SO}_{2}$ absorption on surfaces (Prince et al., 2007; Al-Hosney and Grassian, 2005; Li et al., 2006; Ullerstam et al., 2002; Martin et al., 1987; Usher et al., 2002). The broad band between 1000 and $885 \mathrm{~cm}^{-1}$ in the $\mathrm{CaCO}_{3}$ spectrum is composed of more than 
one peak and is corresponding to the absorptions of sulfite $\left(\mathrm{SO}_{3}^{2-}\right)$ on the surface. Our experimental results showed that sulfite was the major product when $\mathrm{CaCO}_{3}$ was exposed to $\mathrm{SO}_{2}$ under dry air, consistent with earlier studies (Al-Hosney and Grassian, 2005). Then the $\mathrm{SO}_{2}$ flow was cut off, and $\mathrm{O}_{3}$ was introduced into the reaction system after the adsorption of $\mathrm{SO}_{2}$ for $120 \mathrm{~min}$. The broad band between 1000 and $885 \mathrm{~cm}^{-1}$ disappeared within a few minutes while the one between 1240 and $1012 \mathrm{~cm}^{-1}$ assigned to sulfate appeared (Fig. 2d, e, f). Ion chromatography (IC) was used to confirm the formation of sulfite and sulfate. A sharp sulfite peak was found in the IC chromatogram when $\mathrm{SO}_{2}$ was absorbed alone, while there was only a sulfate peak after introducing $\mathrm{O}_{3}$. This experiment indicated that $\mathrm{SO}_{2}$ can adsorb on $\mathrm{CaCO}_{3}$ surface to form sulfite and then sulfite can immediately be oxidized to sulfate in the presence of ozone. In the second experiment, the exposure sequence was reversed. When $\mathrm{O}_{3}$ was solely introduced over the particles surface, IR spectroscopy did not detect the characteristic absorption band of adsorbed $\mathrm{O}_{3}$ species $\left(1000-1100 \mathrm{~cm}^{-1}\right)$ on the surface after the exposure to $\mathrm{O}_{3}$ for $60 \mathrm{~min}$. Then the $\mathrm{O}_{3}$ flow was stopped and $\mathrm{SO}_{2}$ was introduced to the reaction system. DRIFTS spectra showed that the sulfate absorption bands were weak and the major products were sulfite. Ion chromatographic analysis of the leachate obtained after the reaction showed the presence of sulfite, and it is notable that some sulfate was observed. Therefore, $\mathrm{O}_{3}$ mainly reversibly adsorbed on the surface of $\mathrm{CaCO}_{3}$ in absence of $\mathrm{SO}_{2}$, which was also demonstrated by other studies (Ullerstam et al., 2002; Li et al., 2006).

\subsection{Temperature effects}

The effect of temperature (230 to $298 \mathrm{~K})$ on the heterogeneous oxidation of sulfur dioxide $\left(4.9 \times 10^{14}\right.$ molecules $\left.\mathrm{cm}^{-3}\right)$ by ozone $\left(4.9 \times 10^{14}\right.$ molecules $\left.\mathrm{cm}^{-3}\right)$ on $\mathrm{CaCO}_{3}$ at ambient pressure had been studied. At the beginning of this study, an experiment was carried out to investigate whether the temperature would affect the IR signal or not. In this experiment, the integrated absorbance of sulfate with the same concentration $\left(2.4 \mathrm{mg} \mathrm{g}^{-1}\right)$ was investigated as a function of temperature (as shown in Fig. S1). The slope, which was close to zero, indicated that the IR signal intensity of sulfate was approximately independent of temperature in the temperature range used in our study. On the basis of this conclusion, the series of experiments described below were carried out. The results showed that the rate of sulfate formation and the uptake coefficient were sensitive to temperature.

\subsubsection{Temperature effect on the transition region}

The kinetics of the heterogeneous oxidation of $\mathrm{SO}_{2}$ by $\mathrm{O}_{3}$ on the surface of $\mathrm{CaCO}_{3}$ particles were followed using the integrated absorbance-reaction time behavior instead of the Kubelka-Munk function which is known to give rise to unac-

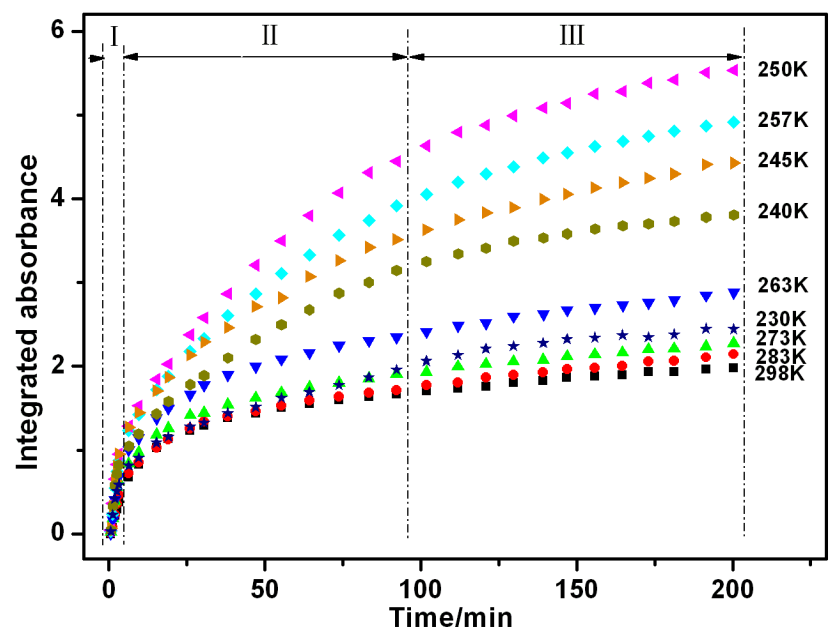

Fig. 3. The integrated absorbance of $1012-1240 \mathrm{~cm}^{-1}$ for sulfate for a series temperatures as a function of reaction time. I, II, and III stand for the initial region, the transition region, and the saturation region, respectively.

ceptable uncertainty levels in quantitative experiments (Vogt and Finlayson-Pitts, 1994; Samuels et al., 2006). The integrated absorbance of $1012-1240 \mathrm{~cm}^{-1}$ for sulfate for a series of temperatures as a function of reaction time are shown in Fig. 3. Two stages, the initial region and the saturation region, were usually considered for the kinetics study at room temperature ( $\mathrm{Li}$ et al., 2006; Ge et al., 2009). As shown in Fig. 3, these two stages are observed at temperatures from 230 to $298 \mathrm{~K}$. As soon as the reactive gas was introduced into the particle layers, the IR bands increased quickly, and the initial region emerged. After a certain time, when the IR bands increased at a stable speed the saturation region appeared. However, an interesting stage which lasted about $80 \mathrm{~min}$ was observed at temperatures ranging from 230 to $257 \mathrm{~K}$ in the present study. During this stage, the IR bands increased a little more slowly than in the initial region while faster than in the saturation region. This stage was named as transition region. The higher the temperature, the shorter time the transition region lasted. For temperatures above $257 \mathrm{~K}$, the initial region transformed to the saturation region so quickly (in minutes) that the transition region became gradually ambiguous. Hence, there may be physical-chemical processes, which influence the reaction in a different way as a function of temperature.

A series of experiments were carried out as a function of ozone concentration $\left[(2.8-7.4) \times 10^{14}\right.$ molecules $\left.\mathrm{cm}^{-3}\right]$ at four model temperatures. Double-logarithmic plots of the rate of sulfate formation as a function of the concentration of $\mathrm{O}_{3}$ at $298 \mathrm{~K}$ (Fig. S2a), $273 \mathrm{~K}$ (Fig. S2b), $263 \mathrm{~K}$ (Fig. S2c), and $240 \mathrm{~K}$ (Fig. S2d) give a series of slopes from a linear regression. All these slopes are close to zero, indicating zero-order overall rate law for $\mathrm{O}_{3}$ in the heterogeneous oxidation of $\mathrm{SO}_{2}$ on the $\mathrm{CaCO}_{3}$ surface 
and that the rate of sulfate formation is independent of the concentration of $\mathrm{O}_{3}$ from $2.8 \times 10^{14}$ molecules $\mathrm{cm}^{-3}$ to $7.4 \times 10^{14}$ molecules $\mathrm{cm}^{-3}$.

According to the analysis and the results of our experiments, three major steps are proposed for the heterogeneous oxidation of $\mathrm{SO}_{2}$ by $\mathrm{O}_{3}$ on the surface of $\mathrm{CaCO}_{3}$ particles. The first proposed step is the rapid adsorption of gas-phase $\mathrm{SO}_{2}$ onto the surface of $\mathrm{CaCO}_{3}$. The reaction is expressed in Reaction (R1), where (g) and (ads) symbols denote gasphase and adsorbed-phase, respectively.

$\mathrm{SO}_{2}(\mathrm{~g}) \underset{k_{-1}}{\stackrel{k_{1}}{\rightleftharpoons}} \mathrm{SO}_{2}($ ads $)$

The second step is the direct reaction of adsorbed-phase $\mathrm{SO}_{2}$ with the $\mathrm{CaCO}_{3}$ surface to yield sulfite ion and $\mathrm{CO}_{2}$. The reaction between $\mathrm{SO}_{2}$ and $\mathrm{CaCO}_{3}$ is thermodynamically favorable (Usher et al., 2002). On the surface of dry $\mathrm{CaCO}_{3}$, $\mathrm{SO}_{2} \rightarrow \mathrm{SO}_{3}^{2-}$ conversion takes place via the direct transfer of $\mathrm{O}^{2-}$ from $\mathrm{CO}_{3}^{2-}$ to an adsorbed-phase $\mathrm{SO}_{2}$ molecule (Thompson and Palmer, 1988; Krebs and Nathanson, 2010). The reaction of adsorbed-phase $\mathrm{SO}_{2}$ with the $\mathrm{CaCO}_{3}$ can be expressed as

$\mathrm{CaCO}_{3}(\mathrm{~s})+\mathrm{SO}_{2}(\mathrm{ads}) \stackrel{k_{2}}{\longrightarrow} \mathrm{CaSO}_{3}(\mathrm{ads})+\mathrm{CO}_{2}(\mathrm{~g})$

Finally, sulfite was rapidly oxidized to sulfate in the presence of ozone. This reaction is irreversible and very fast ( $\mathrm{Li}$ et al., 2006). The reaction can be expressed as

$\mathrm{CaCO}_{3}(\mathrm{ads})+\mathrm{O}_{3}(\mathrm{~g}) \stackrel{k_{3}}{\longrightarrow} \mathrm{CaSO}_{4}(\mathrm{ads})+\mathrm{O}_{2}(\mathrm{~g})$

Thus, the rate of sulfate formation was deduced according to the steady-state approximation. Further details of the derivation have been described in detail elsewhere (Li et al., 2006).

$r=\frac{d\left\{\mathrm{SO}_{4}^{2-}\right\}}{d t}=\frac{k_{1} k_{2}}{k_{-1}+k_{2}}\left[\mathrm{SO}_{2}\right]=k\left[\mathrm{SO}_{2}\right]$

where $k$ is the rate constant: $k=\frac{k_{1} k_{2}}{k_{-1}+k_{2}}$.

From Eq. (1), we can see that the reaction is zero order for $\mathrm{O}_{3}$. Therefore, the reaction order deduced from the proposed mechanism is well consistent with the experiment results shown in Fig. S2. Since the above mechanism is deduced within restricted experimental conditions, it should be clarified that it can't be used under all conditions without further proof.

According to Eq. (1), the sulfate formation rate is dependent on $k_{1}, k_{-1}, k_{2}$, which are related to the formation of sulfite. That means, Reactions (R1) and (R2) determine the rate simultaneously. On one hand, the evolution of the integrated absorbance of the sulfite and sulfate during the sequential exposure experiment to $\mathrm{SO}_{2}$ and $\mathrm{O}_{3}$ is illustrated in Fig. S3. This experiment indicated that $\mathrm{SO}_{2}$ could adsorb on
$\mathrm{CaCO}_{3}$ surface to form sulfite and then sulfite could immediately be oxidized to sulfate in the presence of ozone. Compared to the oxidation of sulfite, it takes more time for the formation of sulfite. On the other hand, no kinetic parameters are available for the $\mathrm{S}(\mathrm{IV})$ oxidation involving $\mathrm{SO}_{2} \cdot \mathrm{H}_{2} \mathrm{O}$, $\mathrm{HSO}_{3}^{-}$or $\mathrm{SO}_{3}^{2-}$ on particle surfaces so far, the corresponding aqueous-phase kinetic parameters are used as an estimation (Li et al., 2006). For the aqueous phase reaction: $\mathrm{S}(\mathrm{IV})+\mathrm{O}_{3} \rightarrow \mathrm{S}(\mathrm{IV})+\mathrm{O}_{2}$, the expression for the rate of the reaction of $\mathrm{S}(\mathrm{IV})$ with dissolved ozone is: $R_{0}=-\frac{d[\mathrm{~S}(\mathrm{IV})]}{d t}=$ $\left(k_{0}\left[\mathrm{SO}_{2} \mathrm{H}_{2} \mathrm{O}\right]+k_{1}\left[\mathrm{HSO}_{3}^{-}\right]+k_{2}\left[\mathrm{SO}_{3}^{2-}\right]\right)\left[\mathrm{O}_{3}\right]$ with $k_{0}=2.4 \pm$ $1.1 \times 10^{4} \mathrm{M}^{-1} \mathrm{~s}^{-1}, k_{1}=3.7 \pm 0.7 \times 10^{5} \mathrm{M}^{-1} \mathrm{~s}^{-1}, k_{2}=1.5 \pm$ $0.6 \times 10^{9} \mathrm{M}^{-1} \mathrm{~s}^{-1}$ (Hoffmann and Calvert, 1985). The rate constants above indicate that the reaction between $\mathrm{SO}_{3}^{2-}$ and $\mathrm{O}_{3}$ is the fastest.

At the beginning of the whole reaction, the coverage of adsorbed-phase $\mathrm{SO}_{2}$ was relatively low compared to the large number of reactive sites on the surface. Thus adsorbed-phase $\mathrm{SO}_{2}$ converted rapidly to form the sulfite on the surface and then the initial region emerged. The rapid conversion of adsorbed-phase $\mathrm{SO}_{2}$ to sulfite continued until sterically and energetically suitable sites usable for sulfite formation have been diminished (Low et al., 1971). Continued uptake of $\mathrm{SO}_{2}$ leads to some further sulfite formation. The transition region appeared at temperatures from 230 to $257 \mathrm{~K}$ during this process, which means more sites with less activity on the surface at lower temperature (Liu et al., 2010). But there is less thermal energy available for the reaction to overcome the activation energy, which will be calculated in Sect. 3.2.2. And then it may need more time to complete the whole reaction at low temperature. Thus the transition region lasted for a longer time and became more obvious at low temperature. After a certain time, more and more reactive sites were taken up by the product so that the numbers of reactive sites available for reaction became less. Therefore, the rate of sulfate formation slowed down, resulting in the saturation region.

\subsubsection{Temperature effect on the rate of sulfate formation}

The $\mathrm{SO}_{2}$ concentration was kept constant (using a continuous flow) in the present study. Ordinarily one may expect the reaction rate to decrease with temperature because the rate constant for the reaction decreases with temperature. However, it was found that the rate of sulfate formation increased slowly at the beginning and then decreased with decreasing temperature. In order to quantify the rate of sulfate formation $\mathrm{d}\left\{\mathrm{SO}_{4}^{2-}\right\} / \mathrm{dt}$, the amount of sulfate ions formed during the reaction on the particulate sample was determined by the DRIFTS calibration curve. Referring to the method of the linear correlation in the literature (Martin et al., 1987; Li et al., 2006), the DRIFTS calibration curve was made by mixing a weighed amount of pure $\mathrm{CaSO}_{4}$ uniformly into $\mathrm{CaCO}_{3}$ to a certain concentration. The rate of sulfate formation was translated from absorption units $\mathrm{s}^{-1}$ to $\mathrm{SO}_{4}^{2-} \mathrm{s}^{-1}$ by a 


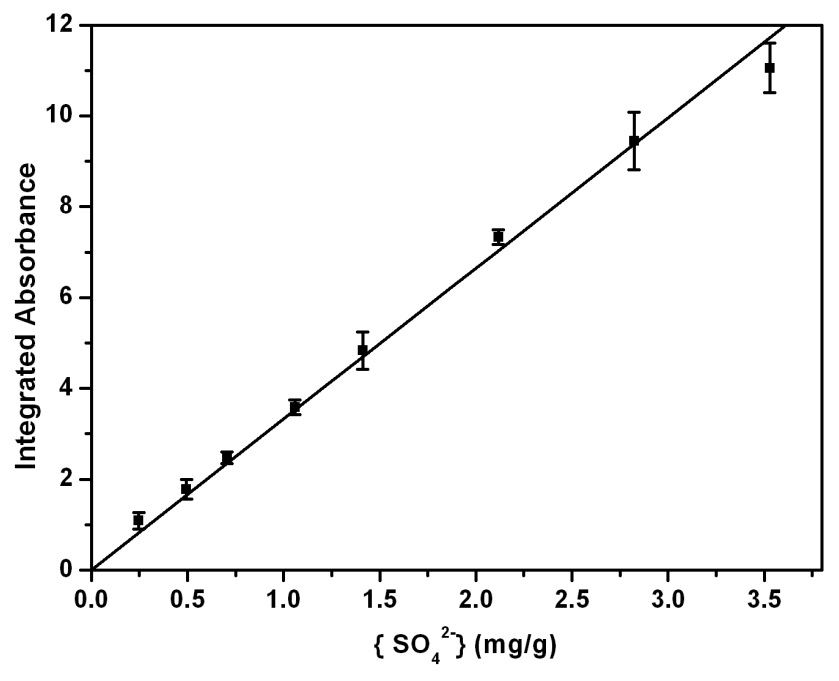

Fig. 4. Calibration curve for the integrated absorbance versus the concentration of sulfate.

conversion factor obtained from a calibration plot (Fig. 4). The plot shows that over a large concentration range the DRIFTS signal is proportional to the sulfate concentration. And the plot gives a conversion factor that enables calculation of the amount of sulfate formed during the reaction. The sulfate ions concentrations:

(integrated absorbance) $\times f=\left\{\mathrm{SO}_{4}^{2-}\right\}$

$f$ was the conversion factor, and the calculated value for sulfate is $1.91 \times 10^{18}$ ions $^{-1} \mathrm{ABU}^{-1}$.

As can be seen in Fig. 5, the rate of sulfate formation increased with decreasing temperature in the range of 298 to $250 \mathrm{~K}$, while it was reversed in the range of 250 to $230 \mathrm{~K}$. That is, the rate of sulfate formation had a maximum value at about $250 \mathrm{~K}$. To our knowledge, this kind of temperature effect on the heterogeneous oxidation of $\mathrm{SO}_{2}$ is the first one reported. Previous literature (Koehler et al., 1999) did report that $\mathrm{SO}_{2}$ adsorption on soot at colder temperatures leads to higher coverage compared to $\mathrm{SO}_{2}$ adsorption on soot at room temperature. Several measurements have carried out to study $\mathrm{SO}_{2}$ uptake onto ice and found it is enhanced at high temperatures (Clegg and Abbatt, 2001; Abbatt, 2003). However, it is scarce that a turning point appears at the experimental temperatures. It indicates that it may involve more complicate processes at low temperature than at room temperature.

Figure 5 shows the linear regression of the rate of sulfate formation $\mathrm{d}\left\{\mathrm{SO}_{4}^{2-}\right\} / \mathrm{dt}$ with the reciprocal value of temperature $(1 / T)$ at temperatures between $245 \mathrm{~K}$ and $230 \mathrm{~K}$. The correlation between the experimental data and the generalized lines under least-square fitting is very good, with $R / R^{2}>0.999$. Therefore, the rate of sulfate formation $d\left\{\mathrm{SO}_{4}^{2-}\right\} / d t$ at temperatures between $245 \mathrm{~K}$ and $230 \mathrm{~K}$ can be described in the form of an Arrhenius expression, $\ln d\left\{\mathrm{SO}_{4}^{2-}\right\} / d t=48.23-1759.24 / T$. The activation energy for

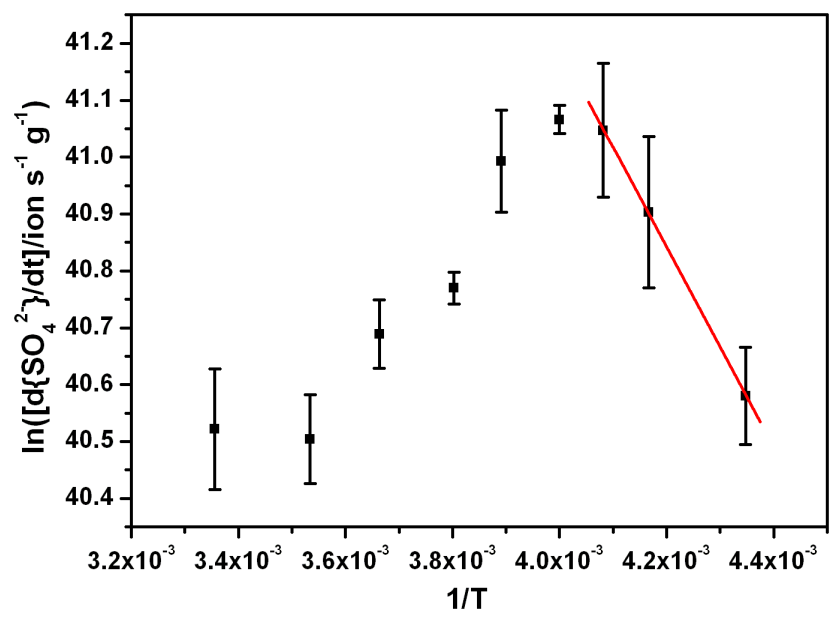

Fig. 5. The relationship between formation rate of sulfate and temperature. The red solid line is the linear regression of the rate of sulfate formation $d\left\{\mathrm{SO}_{4}^{2-}\right\} / d t$ with the reciprocal value of temperature $(1 / T)$ at temperatures below $250 \mathrm{~K}$. The slope is $-1759.24 \pm 23.58$ $(\sigma)$.

the reaction was determined to be $14.63 \pm 0.20 \mathrm{~kJ} \mathrm{~mol}^{-1}$. Usually, reactions with activation energies greater than $20 \mathrm{~kJ} \mathrm{~mol}^{-1}$ are regarded to be too slow to play a significant role in atmospheric chemistry (Smith, 2003). It suggests that even at low temperature the heterogeneous oxidation of sulfur dioxide by ozone on $\mathrm{CaCO}_{3}$ should not be neglected in the troposphere.

According to Eq. (1), the rate of sulfate formation is proportional to the rate constant and the concentration of gasphase $\mathrm{SO}_{2}$. Since the concentration of gas-phase $\mathrm{SO}_{2}$ was kept constant, the rate constant was the only factor that influenced the rate of sulfate formation. All rate constants $\left(k_{1}\right.$, $k_{-1}$, and $k_{2}$ ) would decrease with decreasing temperature in terms of an Arrhenius expression. The forward Reactions of (R1) and (R2) that favor sulfate formation would slow down with decreasing $k_{1}$ and $k_{2}$ while desorption of $\mathrm{SO}_{2}\left(k_{-1}\right)$ would also get slower. The combined effect of these two opposing trends is represented in the expression $k=\frac{k_{1} k_{2}}{k_{-1}+k_{2}}$. Its limiting cases can be used to interpret the temperature effect on the rate of sulfate formation. If the value of $k_{-1}$ was small enough to be neglected against $k_{2}$, then the rate constant $\mathrm{k}$ would approach $k_{1}$. In this case, the adsorption of gas-phase $\mathrm{SO}_{2}$ to the surface of $\mathrm{CaCO}_{3}$ was the rate determining step in the whole mechanism and its desorption was nearly negligible. The apparent activation energy is expressed as:

$E_{a}=\mathrm{RT}^{2} \frac{d \ln k}{d(1 / \mathrm{T})}=\mathrm{RT}^{2} \frac{d \ln k_{1}}{d(1 / \mathrm{T})}=E_{a 1}$

where $E_{a}$ is the apparent activation energy, and $E_{a 1}$ is the activation energy for the adsorption of gas-phase $\mathrm{SO}_{2}$ to the surface of $\mathrm{CaCO}_{3}$. The apparent activation energy $E_{a}$ has a positive non-zero value in this case. On the contrary, if $k_{2}$ 
was small enough to be neglected against $k_{-1}$, the rate constant $\mathrm{k}$ would approach $\frac{\mathrm{k}_{1} k_{2}}{k_{-1}}=K k_{2}$, where $\mathrm{K}$ is the equilibrium constant of Reaction (R1). Thus the apparent activation energy can be expressed as:

$$
\begin{aligned}
& E_{a}= \mathrm{RT}^{2} \frac{d \ln k}{d(1 / T)}=\mathrm{RT}^{2} \frac{d \ln \left(K k_{2}\right)}{d\left(^{1} / T\right)}=\mathrm{RT}^{2} \frac{d \ln (K)}{d\left(^{1} / T\right)}+ \\
& \mathrm{RT}^{2} \frac{d \ln \left(k_{2}\right)}{d(1 / T)}=\Delta H_{\mathrm{ads}}+E_{\mathrm{a} 2}
\end{aligned}
$$

where $E_{a 2}$ is the activation energy for the reaction between the adsorbed-phase $\mathrm{SO}_{2}$ and $\mathrm{CaCO}_{3} . \Delta H_{\text {ads }}$ is the enthalpy for gas-phase $\mathrm{SO}_{2}$ adsorption on $\mathrm{CaCO}_{3}$ surface. It has been reported that the reversible adsorption of gas-phase $\mathrm{SO}_{2}$ is exothermic (Clegg and Abbatt, 2001). Therefore, it is reasonable to assume that $\Delta H_{\text {ads }}<0$. To our knowledge, there is no direct value of the enthalpy for gas-phase $\mathrm{SO}_{2}$ adsorption on $\mathrm{CaCO}_{3}$ surface so that available enthalpy values $\left(-26.13 \mathrm{~kJ} \mathrm{~mol}^{-1}\right)$ for $\mathrm{SO}_{2}$ adsorption on the liquid water surface (Smith and Martell, 1982; Conklin and Bales, 1993) is used as an estimate. Therefore, $E_{a}$ can adopt a negative value and the forward pathways of Reactions (R1) and (R2) play a critical role in this case.

As shown in Fig. 5, the activation energy for the whole reaction has a negative value at temperatures from 298 to $250 \mathrm{~K}$. According to the above two extreme cases, the value of $E_{a}$ could exist as negative value only if the second extreme case dominated in the whole reaction. That means, adsorption and conversion to sulfite (the forward Reaction of R1 and R2) that promoted sulfate formation dominated in the whole heterogeneous reaction at high temperature. At temperatures below $250 \mathrm{~K}$, the activation energy for the whole reaction was determined to be $14.63 \pm 0.20 \mathrm{~kJ} \mathrm{~mol}^{-1}$. It suggested that the first extreme case became more and more important. Less active sites could be explored with decreasing temperature so that the adsorption of gas-phase $\mathrm{SO}_{2}$ became slow and then played an important role in the whole reaction at temperatures below $250 \mathrm{~K}$. When adsorption $\left(k_{1}\right)$ and reaction $\left(k_{2}\right)$ were counterbalanced by desorption $\left(k_{-1}\right)$, the turning point emerged. And at this moment, the apparent activation energy approached zero.

After $\mathrm{CaCO}_{3}$ particles were exposed simultaneously to $\mathrm{SO}_{2}\left(4.9 \times 10^{14}\right.$ molecules $\left.\mathrm{cm}^{-3}\right)$ and $\mathrm{O}_{3}\left(4.9 \times 10^{14}\right.$ molecule $\mathrm{cm}^{-3}$ ) for $200 \mathrm{~min}$, the concentrations of sulfate ions at different temperatures were determined, as shown in Fig. 6. The concentrations of sulfate ions showed a similar trend as the rate of sulfate formation. It showed that the sulfate ions concentration varied with the temperature and reached a maximum value at a temperature near $250 \mathrm{~K}$ in the range of 230 to $298 \mathrm{~K}$. The sulfate concentration at $250 \mathrm{~K}$ was about twice as high as that at $298 \mathrm{~K}$. As discussed above, the rate of sulfate formation decreased and less sites with higher activity could be explored as temperature decreased to below $250 \mathrm{~K}$. In this case, the corresponding total accumulated sulfate concentration at $200 \mathrm{~min}$ would decrease. On

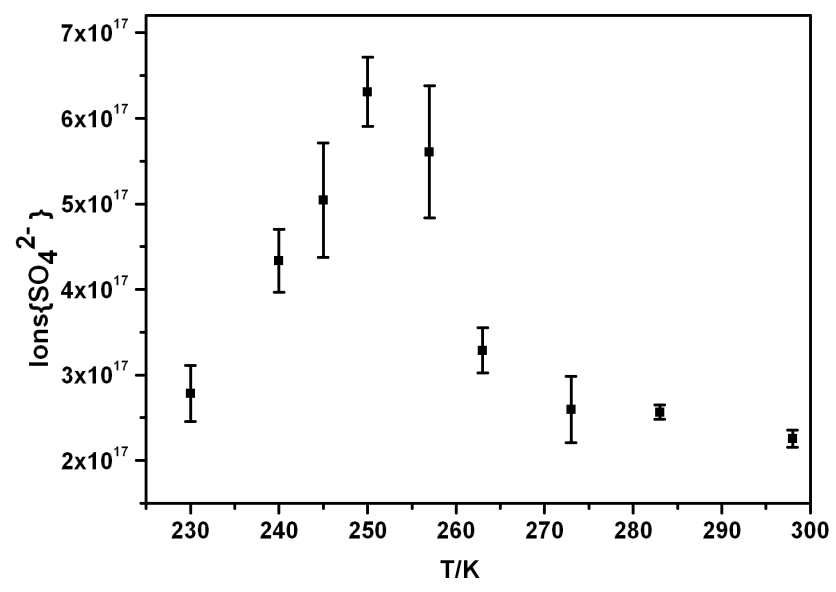

Fig. 6. The concentrations of sulfate ions at different temperatures after $\mathrm{CaCO}_{3}$ particles exposed simultaneously to $\mathrm{SO}_{2}$ $\left(4.9 \times 10^{14}\right.$ molecules $\left.\mathrm{cm}^{-3}\right)$ and $\mathrm{O}_{3}\left(4.9 \times 10^{14}\right.$ molecules $\left.\mathrm{cm}^{-3}\right)$ for $200 \mathrm{~min}$.

the contrary, the rate of sulfate formation increased and reaction R1 reverse slowed down as temperature decreased from 298 to $250 \mathrm{~K}$. Then the corresponding total accumulated sulfate concentration at $200 \mathrm{~min}$ increased.

\subsubsection{Temperature effect on the uptake coefficient}

To compare this study to others in the literature, the reactive uptake coefficient $(\gamma)$ for the heterogeneous oxidation of $\mathrm{SO}_{2}$ was deduced from the DRIFTS experiments. The reactive uptake coefficient, $\gamma$, is defined as the rate of product formation $\left(d\left\{\mathrm{SO}_{4}^{2-}\right\} / d t\right)$ divided by the rate of surface collisions per unit time $(Z)$.

$\gamma=\frac{d\left\{\mathrm{SO}_{4}^{2-}\right\} / d t}{Z}$

$Z=\frac{1}{4} \bar{c} A_{\text {surface }}\left[\mathrm{SO}_{2}\right]$

$\bar{c}=\sqrt{\frac{8 \mathrm{RT}}{\pi M_{\mathrm{SO}_{2}}}}$

where $\bar{c}$ is the mean molecular velocity of $\mathrm{SO}_{2}, R$ is the gas constant, $T$ is the temperature and $M_{\mathrm{SO}_{2}}$ is the molecular weight of $\mathrm{SO}_{2}, A_{\text {surface }}$ is the effective sample surface. Concentrations marked with \{ \} indicate surface species, whereas [ ] indicate the concentration of gas-phase species.

It was suggested that two extreme cases of effective sample surface should be considered for calculating the uptake coefficient (Li et al., 2006; Tong et al., 2010; Ullerstam et al., 2002). For the same heterogeneous reaction, the uptake coefficients can differ by about four orders of magnitude depending on the choice of the effective surface area (geometric 
or BET area) (Tong et al., 2010). If the reaction probability is high, the reactants would have no time to diffuse into the sample before reacting and the effective surface area will be the geometric surface area of the sample. If the reaction probability is low, the reactants may have enough time to diffuse into the entire sample and thus the BET surface area would more appropriately represent the effective area. When sulfate formed is evenly distributed into the sample, the uptake coefficients obtained using the geometric area will be overestimated. Therefore, the uptake coefficients obtained from the geometric and BET surface area as the reactive surface area should be considered as upper and lower limits, respectively. Given that the BET surface area best represents the reactive surface under atmospheric conditions, the uptake coefficients are usually given and compared based on BET area (Börensen et al., 2000; Crowley et al., 2010). However, the geometric surface area of the particles is usually used in the heterogeneous atmospheric chemistry modeling studies because atmospheric chemistry models usually calculated aerosol surface area on the basis of the particle diameter. In order to compare with the results of other studies and to employ the atmospheric chemistry models, we have calculated two kinds of uptake coefficients based on BET and geometric areas respectively.

There have been several studies concerning the uptake of $\mathrm{SO}_{2}$ and $\mathrm{O}_{3}$ on different surfaces or materials using DRIFTS reactors (Ullerstam et al., 2002; Li et al., 2006, 2007; Ge et al., 2009), and most of them were deduced from results at room temperature. Uptake coefficients determined for $\mathrm{SO}_{2}$ oxidation by $\mathrm{O}_{3}$ on different particulates using a BET surface at room temperature are listed in Table 1. The data from Table 1 can be used for a comparison of the uptake coefficients for $\mathrm{SO}_{2}$ in the presence of $\mathrm{O}_{3}$ at room temperature with different experiment studies. For the different substances, the uptake coefficients can differ by about one order of magnitude using the same type of measurement technique. However, our experiment result $\gamma_{0}=1.27 \times 10^{-7}$ at room temperature was close to that with $\gamma_{0}=1.4 \times 10^{-7}$ on $\mathrm{CaCO}_{3}$ particle ( $\mathrm{Li}$ et al., 2006). It indicated that our experiments were valid. The little difference in uptake coefficient was likely caused by many factors such as, experimental artifacts, the way of measurement evaluation, and the difference between the BET surface area (the particles used by Li et al (2006) was $1.95 \mathrm{~m}^{2} \mathrm{~g}^{-1}$, while our particles was $1.35 \mathrm{~m}^{2} \mathrm{~g}^{-1}$ ).

The reactive uptake coefficients at temperatures from 230 to $298 \mathrm{~K}$ are listed in Table 2. Since the transition region was ambiguous at temperatures above $257 \mathrm{~K}$, the transition region uptake coefficients $\left(\gamma_{\text {tr }}\right)$ at temperatures from 263 to $298 \mathrm{~K}$ are not given. The reactive uptake coefficients at these different temperatures can be used directly in atmospheric chemistry modeling studies to predict the formation of secondary sulfate aerosol in the troposphere. As shown in Table 2 , the reactive uptake coefficients are sensitive to the temperature. Both the initial region uptake coefficient $\left(\gamma_{0}\right)$ and the saturation region uptake coefficient $\left(\gamma_{\mathrm{sr}}\right)$ are found to in-
Table 1. Reactive uptake coefficients determined for $\mathrm{SO}_{2}$ oxidation by $\mathrm{O}_{3}$ on different particulates using a BET surface at room temperature.

\begin{tabular}{|c|c|c|c|}
\hline Gas & Particulates & Reference & $\gamma_{0}$ \\
\hline $\mathrm{SO}_{2}+\mathrm{O}_{3}$ & Saharan dust & Ullerstam et al. (2002) & $5 \times 10^{-7}$ \\
\hline $\mathrm{SO}_{2}+\mathrm{O}_{3}$ & $\mathrm{NaCl}$ & Li et al. (2007) & $4.3 \times 10^{-8}$ \\
\hline $\mathrm{SO}_{2}+\mathrm{O}_{3}$ & Basic $\mathrm{Al}_{2} \mathrm{O}_{3}$ & Ge et al. (2009) & $7 \times 10^{-7}$ \\
\hline $\mathrm{SO}_{2}+\mathrm{O}_{3}$ & Neutral $\mathrm{Al}_{2} \mathrm{O}_{3}$ & Ge et al. (2009) & $3 \times 10^{-7}$ \\
\hline $\mathrm{SO}_{2}+\mathrm{O}_{3}$ & Acidic $\mathrm{Al}_{2} \mathrm{O}_{3}$ & Ge et al. (2009) & $2 \times 10^{-7}$ \\
\hline $\mathrm{SO}_{2}+\mathrm{O}_{3}$ & $\mathrm{CaCO}_{3}$ & Li et al. (2006) & $1.4 \times 10^{-7}$ \\
\hline $\mathrm{SO}_{2}+\mathrm{O}_{3}$ & $\mathrm{CaCO}_{3}$ & This work & $1.27 \times 10^{-7}$ \\
\hline
\end{tabular}

crease with decreasing temperature at temperatures from 298 to $250 \mathrm{~K}$, and decrease with decreasing temperature at temperatures from 250 to $230 \mathrm{~K}$. And the transition region uptake coefficient also has a maximum value at about $250 \mathrm{~K}$. Thus, temperature should receive more attention when studying the kinetics of the heterogeneous reaction.

Two factors, the mean molecular velocity of $\mathrm{SO}_{2}$ and the rate constant of sulfate formation $\left(k=\frac{d\left\{\mathrm{SO}_{4}^{2-}\right\} d t}{\left[\mathrm{SO}_{2}\right]}\right.$ according to Eq. (1)), are related to temperature when the reactive uptake coefficients at different temperatures were calculated. On the basis of the Eqs. (5), (6), and (7), the reactive uptake coefficient would be proportional to $\sqrt{\frac{1}{T}}$ When $\frac{d\left\{\mathrm{SO}_{4}^{2-}\right\} / d t}{\left[\mathrm{SO}_{2}\right]}$ was kept constant. That is, if the mean molecular velocity of $\mathrm{SO}_{2}$ is the only factor considered, the reactive uptake coefficients would monotonically increase with the temperature decrease and there would no maximum value appearing in the reactive uptake coefficients. Additionally, the reactive uptake coefficients had a similar trend as the sulfate formation as a function of temperature, which has been discussed above. Therefore, the rate constant of sulfate formation instead of the mean molecular velocity of $\mathrm{SO}_{2}$ may be a major factor that can be used to explain the effect of temperature on the reactive uptake coefficients.

\section{Conclusions and atmospheric implications}

In this study, the influence of temperature on the heterogeneous oxidation of sulfur dioxide by ozone on $\mathrm{CaCO}_{3}$ has been investigated by DRIFTS. Since the kinetics and mechanisms were determined at room temperature previously ( $\mathrm{Li}$ et al., 2006), our research focused on the question of whether the products depend on the temperature and how the rate of sulfate formation vary with the change of temperature in the range from $230 \mathrm{~K}$ to $298 \mathrm{~K}$. The kinetics and mechanism of the heterogeneous oxidation were followed by monitoring IR spectral changes as a function of time. Compared to the reaction at room temperature, there is no new species observed on the surface at low temperature. However, we found that there 


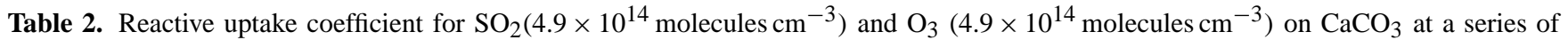
tropospheric temperatures.

\begin{tabular}{|c|c|c|c|c|c|c|}
\hline \multirow[b]{2}{*}{$\mathrm{T} / \mathrm{K}$} & \multicolumn{2}{|c|}{$\gamma_{0}$} & \multicolumn{2}{|c|}{$\gamma_{\mathrm{tr}}$} & \multicolumn{2}{|c|}{$\gamma_{\mathrm{sr}}$} \\
\hline & $\begin{array}{c}\text { Geometric } \\
10^{-4}\end{array}$ & $\begin{array}{l}\text { BET } \\
10^{-7}\end{array}$ & $\begin{array}{c}\text { Geometric } \\
10^{-5}\end{array}$ & $\begin{array}{l}\text { BET } \\
10^{-8}\end{array}$ & $\begin{array}{c}\text { Geometric } \\
10^{-6}\end{array}$ & $\begin{array}{l}\text { BET } \\
10^{-9}\end{array}$ \\
\hline 298 & $1.31 \pm 0.13$ & $1.27 \pm 0.13$ & - & - & $1.87 \pm 0.14$ & $1.81 \pm 0.11$ \\
\hline 283 & $1.32 \pm 0.10$ & $1.28 \pm 0.10$ & - & - & $2.46 \pm 0.32$ & $2.37 \pm 0.29$ \\
\hline 273 & $1.62 \pm 0.10$ & $1.56 \pm 0.09$ & - & - & $2.31 \pm 0.31$ & $2.23 \pm 0.30$ \\
\hline 263 & $1.78 \pm 0.05$ & $1.73 \pm 0.05$ & - & - & $3.35 \pm 0.17$ & $3.24 \pm 0.16$ \\
\hline 257 & $2.27 \pm 0.20$ & $2.19 \pm 0.19$ & $2.16 \pm 0.47$ & $2.09 \pm 0.46$ & $5.70 \pm 1.06$ & $5.53 \pm 1.02$ \\
\hline 250 & $2.44 \pm 0.07$ & $2.36 \pm 0.07$ & $2.86 \pm 0.24$ & $2.78 \pm 0.24$ & $6.12 \pm 1.12$ & $5.93 \pm 1.08$ \\
\hline 245 & $2.45 \pm 0.28$ & $2.37 \pm 0.28$ & $2.38 \pm 0.13$ & $2.30 \pm 0.16$ & $5.53 \pm 0.99$ & $5.35 \pm 0.97$ \\
\hline 240 & $2.15 \pm 0.28$ & $2.08 \pm 0.28$ & $1.75 \pm 0.32$ & $1.69 \pm 0.31$ & $3.81 \pm 0.54$ & $3.69 \pm 0.532$ \\
\hline 230 & $1.59 \pm 0.13$ & $1.53 \pm 0.13$ & $0.60 \pm 0.20$ & $0.58 \pm 0.19$ & $4.11 \pm 1.06$ & $3.98 \pm 1.02$ \\
\hline
\end{tabular}

existed an obvious transition region at temperatures from 230 to $257 \mathrm{~K}$, while the transition region became ambiguous at temperatures above $257 \mathrm{~K}$. In addition, the rate of sulfate formation had a maximum value at about $250 \mathrm{~K}$. The sulfate concentration at $250 \mathrm{~K}$ was about twice as high as that at room temperature. At temperatures above $250 \mathrm{~K}$, the rate of sulfate formation increased with decreasing temperature. This is because of the uptake enhancement of gas-phase $\mathrm{SO}_{2}$ at low temperatures. At temperatures below $250 \mathrm{~K}$, less thermal energy available for the reaction resulted in a positive temperature effect on the reaction rate. The rate of sulfate formation from $245 \mathrm{~K}$ to $230 \mathrm{~K}$ can be described in the form of an Arrhenius expression. That is, $\ln d\left\{\mathrm{SO}_{4}^{2-}\right\} / d t=48.23-$ $1759.24 / T$. The activation energy for the reaction was determined to be $14.63 \pm 0.20 \mathrm{~kJ} \mathrm{~mol}^{-1}$. The relatively low activation energy suggests that the heterogeneous oxidation of sulfur dioxide by ozone may still play an important role on the rate of sulfate formation even at low temperature.

As we noted in the introduction, the temperature in the Earth's atmosphere varies with latitude, longitude, and altitude above the Earth's surface, as well as the season and the time of day. The current research is only the first step toward understanding the sulfate formation in the real Earth's atmosphere. Nevertheless, the results in this study do point out that the rate of sulfate formation can be faster at low temperatures compared to room temperature. It is in accord with the fact that serious air pollution episodes have occurred during late fall and early winter months, when $T$ was low (Freiberg, 1974). A three-dimensional global model investigation of seasonal variation in the atmospheric burden of anthropogenic sulfate aerosols has also shown that wintertime column sulfate is predicted to exceed summertime column sulfate by heterogeneous chemical production (Kasibhatla et al., 1997). Therefore, the heterogeneous oxidation of $\mathrm{SO}_{2}$ to sulfate should not be neglected in the whole troposphere, including the high troposphere with low temperature. Further- more, our results also suggested that the temperature could affect the reactive uptake coefficients so that the temperature factor should be considered when the reactive uptake coefficients used in the modeling studies.

\section{Supplementary material related to this article is available online at: http://www.atmos-chem-phys.net/11/6593/2011/ acp-11-6593-2011-supplement.pdf.}

Acknowledgements. This project was supported by Knowledge Innovation Program (Grant No. KJCX2-YW-N24, KZCX2-YWQ02-03, KZCX2-YW-205) of the Chinese Academy of Sciences, and the National Natural Science Foundation of China (Contract No. 40925016, 40830101, 21077109, 41005070).

Edited by: M. Ammann

\section{References}

Abbatt, J. P. D.: Interactions of atmospheric trace gases with ice surfaces: Adsorption and reaction, Chem. Rev., 103, 4783-4800, 2003.

Adams, J. W., Rodriguez, D., and Cox, R. A.: The uptake of $\mathrm{SO}_{2}$ on Saharan dust: a flow tube study, Atmos. Chem. Phys., 5, 2679 2689, doi:10.5194/acp-5-2679-2005, 2005.

Al-Hosney, H. A. and Grassian, V. H.: Carbonic acid: An important intermediate in the surface chemistry of calcium carbonate, $\mathrm{J}$. Am. Chem. Soc., 126, 8068-8069, 2004.

Al-Hosney, H. A. and Grassian, V. H.: Water, sulfur dioxide and nitric acid adsorption on calcium carbonate: A transmission and ATR-FTIR study, Phys. Chem. Chem. Phys., 7, 1266-1276, 2005.

Baltrusaitis, J., Usher, C. R., and Grassian, V. H.: Reactions of sulfur dioxide on calcium carbonate single crystal and particle surfaces at the adsorbed water carbonate interface, Phys. Chem. Chem. Phys., 9, 3011-3024, 2007. 
Bauer, S. E., Mishchenko, M. I., Lacis, A. A., Zhang, S., Perlwitz, J., and Metzger, S. M.: Do sulfate and nitrate coatings on mineral dust have important effects on radiative properties and climate modeling?, J. Geophys. Res.-Atmos., 112, D06307, doi:10.1029/2005JD006977, 2007.

Borensen, C., Kirchner, U., Scheer, V., Vogt, R., and Zellner, R.: Mechanism and kinetics of the reactions of $\mathrm{NO}_{2}$ or $\mathrm{HNO}_{3}$ with alumina as a mineral dust model compound, J. Phys. Chem. A, 104, 5036-5045, 2000.

Botha, C. F., Hahn, J., Pienaar, J. J., and Vaneldik, R.: Kinetics and mechanism of the oxidation of sulfur(IV) by ozone in aqueoussolutions, Atmos. Environ., 28, 3207-3212, 1994.

Cavalieri, O., Cairo, F., Fierli, F., Di Donfrancesco, G., Snels, M., Viterbini, M., Cardillo, F., Chatenet, B., Formenti, P., Marticorena, B., and Rajot, J. L.: Variability of aerosol vertical distribution in the Sahel, Atmos. Chem. Phys., 10, 12005-12023, doi:10.5194/acp-10-12005-2010, 2010.

Clegg, S. M. and Abbatt, J. P. D.: Uptake of gas-phase $\mathrm{SO}_{2}$ and $\mathrm{H}_{2} \mathrm{O}_{2}$ by ice surfaces: Dependence on partial pressure, temperature, and surface acidity, J. Phys. Chem. A, 105, 6630-6636, 2001.

Conklin, M. H. and Bales, R. C.: $\mathrm{SO}_{2}$ uptake on ice spheres - liquid nature of the ice-air interface, J. Geophys. Res.-Atmos., 98, 16851-16855, 1993.

Crowley, J. N., Ammann, M., Cox, R. A., Hynes, R. G., Jenkin, M. E., Mellouki, A., Rossi, M. J., Troe, J., and Wallington, T. J.: Evaluated kinetic and photochemical data for atmospheric chemistry: Volume V - heterogeneous reactions on solid substrates, Atmos. Chem. Phys., 10, 9059-9223, doi:10.5194/acp-10-90592010, 2010.

Cziczo, D. J., Murphy, D. M., Hudson, P. K., and Thomson, D. S.: Single particle measurements of the chemical composition of cirrus ice residue during CRYSTAL-FACE, J. Geophys. Res.Atmos., 109, D04201, doi:10.1029/2003JD004032, 2004.

Dentener, F. J., Carmichael, G. R., Zhang, Y., Lelieveld, J., and Crutzen, P. J.: Role of mineral aerosol as a reactive surface in the global troposphere, J. Geophys. Res.-Atmos., 101, 2286922889, 1996.

Feichter, J., Kjellstrom, E., Rodhe, H., Dentener, F., Lelieveld, J., and Roelofs, G. J.: Simulation of the tropospheric sulfur cycle in a global climate model, Atmos. Environ., 30, 1693-1707, 1996.

Finlayson-Pitts, B. J.: Chemistry of the Upper and Lower Atmosphere-Theory, Experiments, and Applications, Acdemic Press, New York, 2000.

Freiberg, J.: Effects of relative humidity and temperature on ironcatalyzed oxidation of $\mathrm{SO}_{2}$ in atmospheric aerosols, Environ. Sci. Technol., 8, 731-734, 1974.

Fu, H. B., Wang, X., Wu, H. B., Yin, Y., and Chen, J. M.: Heterogeneous uptake and oxidation of $\mathrm{SO}_{2}$ on iron oxides, J. Phys. Chem. C, 111, 6077-6085, 2007.

Fu, H. B., Xu, T. G., Yang, S. G., Zhang, S. C., and Chen, J. M.: Photoinduced Formation of Fe(III)-Sulfato Complexes on the Surface of alpha- $\mathrm{Fe}_{2} \mathrm{O}_{3}$ and Their Photochemical Performance, J. Phys. Chem. C, 113, 11316-11322, 2009.

Ge, M. F., Tong, S. R., Wang, W. G., and Yin, S.: Kinetic and mechanism of $\mathrm{SO}_{2}$ oxidation by $\mathrm{O}_{3}$ on the surface of aluminum oxide particles, Aerosols: Chemistry Environmental Impact and Health Effects, Nova Science Publishers, 2009.

Goodman, A. L., Li, P., Usher, C. R., and Grassian, V. H.: Hetero- geneous uptake of sulfur dioxide on aluminum and magnesium oxide particles, J. Phys. Chem. A, 105, 6109-6120, 2001.

Goudie, A. S. and Middleton, N. J.: Saharan dust storms: nature and consequences, Earth-Sci. Rev., 56, 179-204, 2001.

Hanisch, F. and Crowley, J. N.: Heterogeneous reactivity of gaseous nitric acid on $\mathrm{Al}_{2} \mathrm{O}_{3}, \mathrm{CaCO}_{3}$, and atmospheric dust samples: A Knudsen cell study, J. Phys. Chem. A, 105, 3096-3106, 2001.

Harrison, S. P., Kohfeld K. E., Roelandt, C., and Claquin, T.: The role of dust in climate changes today, at the last glacial maximum and in the future, Earth-Sci. Rev., 54, 43-80, 2001.

Hoffmann, M. R. and Calvert, J. G.: Chemical transformation models for eulerian acid deposition models, The Aqueousphase Chemistry, EPA/600/3-85/017, U.S. Environment Protection Agency, Research Triangle Park, NC, 2, 1985.

Hug, S. J.: In situ Fourier transform infrared measurements of sulfate adsorption on hematite in aqueous solutions, J. Colloid Interface Sci., 188, 415-422, 1997.

Husar, R. B., Tratt, D. M., Schichtel, B. A., Falke, S. R., Li, F., Jaffe, D., Gasso, S., Gill, T., Laulainen, N. S., Lu, F., Reheis, M. C., Chun, Y., Westphal, D., Holben, B. N., Gueymard, C., McKendry, I., Kuring, N., Feldman, G. C., McClain, C., Frouin, R. J., Merril,1 J., DuBois, D., Vignola, F., Murayama, T., Nickovic, S., Wilson, W. E., Sassen, K., Sugimoto, N., and Malm, W. C.: Asian dust events of April 1998, J. Geophys. Res.-Atmos., 106, 18317-18330, 2001.

Jacob, D. J.: Heterogeneous chemistry and tropospheric ozone, Atmos. Environ., 34, 2131-2159, 2000.

Kasibhatla, P., Chameides, W. L., and St John, J.: A threedimensional global model investigation of seasonal variations in the atmospheric burden of anthropogenic sulfate aerosols, J. Geophys. Res.-Atmos., 102, 3737-3759, 1997.

Koehler, B. G., Nicholson, V. T., Roe, H. G., and Whitney, E. S.: A Fourier transform infrared study of the adsorption of $\mathrm{SO}_{2}$ on n-hexane soot from $-130^{\circ}$ to $-40^{\circ} \mathrm{C}$, J. Geophys. Res.-Atmos., 104, 5507-5514, 1999.

Koehler, K. A., Kreidenweis, S. M., DeMott, P. J., Petters, M. D., Prenni, A. J., and Möhler, O.: Laboratory investigations of the impact of mineral dust aerosol on cold cloud formation, Atmos. Chem. Phys., 10, 11955-11968, doi:10.5194/acp10-11955-2010, 2010.

Koretsky, C. M., Sverjensky, D. A., Salisbury ,J. W., and Daria, D. M.: Detection of surface hydroxyl species on quartz, gammaalumina, and feldspars using diffuse reflectance infrared spectroscopy, Geochim. Cosmochim. Acta, 61, 2193-2210, 1997.

Krebs, T. and Nathanson, G. M.: Reactive collisions of sulfur dioxide with molten carbonates, Proc. Natl. Acad. Sci. USA, 107, 6622-6627, 2010.

Langner J., and Rodhe H.: A global 3-dimensional model of the tropospheric sulfur cycle, J. Atmos. Chem., 13, 225-263, 1991.

Laskin, A., Gaspar, D. J., Wang, W. H., Hunt, S. W., Cowin, J. P., Colson, S. D., and Finlayson-Pitts, B. J.: Reactions at interfaces as a source of sulfate formation in sea-salt particles, Science, 301, 340-344, 2003.

Laskin, A., Iedema, M. J., Ichkovich, A., Graber, E. R., Taraniuk, I., and Rudich, Y.: Direct observation of completely processed calcium carbonate dust particles, Faraday Discuss., 130, 453468, 2005.

Levin, Z., Ganor, E., and Gladstein, V.: The effects of desert particles coated with sulfate on rain formation in the eastern Mediter- 
ranean, J. Appl. Meteorol., 35, 1511-1523, 1996.

Li, J. W. and Han, Z. W.: A modeling study of the impact of heterogeneous reactions on mineral aerosol surfaces on tropospheric chemistry over East Asia, Particuology, 8, 433-441, 2010.

Li, L., Chen, Z. M., Zhang, Y. H., Zhu, T., Li, J. L., and Ding, J.: Kinetics and mechanism of heterogeneous oxidation of sulfur dioxide by ozone on surface of calcium carbonate, Atmos. Chem. Phys., 6, 2453-2464, doi:10.5194/acp-6-2453-2006, 2006.

Li, L., Chen, Z. M., Zhang, Y. H., Zhu, T., Li, S., Li, H. J., Zhu, L. H., and $\mathrm{Xu}, \mathrm{B}$. Y.: Heterogeneous oxidation of sulfur dioxide by ozone on the surface of sodium chloride and its mixtures with other components, J. Geophys. Res.-Atmos., 112, D18301, doi:10.1029/2006JD008207, 2007.

Li, X., Maring, H., Savoie, D., Voss, K., and Prospero, J. M.: Dominance of mineral dust in aerosol light-scattering in the North Atlantic trade winds, Nature, 380, 416-419, 1996.

Liu, Y. C., Ma, J. Z., Liu, C., and He, H.: Heterogeneous uptake of carbonyl sulfide onto kaolinite within a temperature range of 220-330 K, J. Geophys. Res.-Atmos., 115, D24311, doi:10.1029/2010JD014778, 2010.

Low, M. J. D., Goodsel, A. J., and Takezawa, N.: Reactions of gaseous pollutants with solids, 1. infrared study of sorption of $\mathrm{SO}_{2}$ on $\mathrm{CaO}$, Environ. Sci. Technol., 5, 1191-1195, 1971.

Luria, M. and Sievering, H.: Heterogeneous and homogeneous oxidation of $\mathrm{SO}_{2}$ in the remote marine atmosphere, Atmospheric Environment Part a-General Topics, 25, 1489-1496, 1991.

Martin, M. A., Childers, J. W., and Palmer, R. A.: FourierTransform Infrared Photoacoustic-Spectroscopy characterization of sulfur-oxygen species resulting from the reaction of $\mathrm{SO}_{2}$ with $\mathrm{CaO}$ and $\mathrm{CaCO}_{3}$, Appl. Spectrosc., 41, 120-126, 1987.

Nishikawa, M., Kanamori, S., Kanamori, N., and Mizoguchi, T.: Kosa aerosol as eolian carrier of anthropogenic material, Sci. Total Environ., 107, 13-27, 1991.

Peak, D., Ford, R. G., and Sparks, D. L.: An in situ ATR-FTIR investigation of sulfate bonding mechanisms on goethite, J. Colloid Interface Sci., 218, 289-299, 1999.

Pham, M., Muller, J. F., Brasseur, G. P., Granier, C., and Megie, G.: A three-dimensional study of the tropospheric sulfur cycle, J. Geophys. Res.-Atmos., 100, 26061-26092, 1995.

Prince, A. P., Kleiber, P., Grassian, V. H., and Young, M. A.: Heterogeneous interactions of calcite aerosol with sulfur dioxide and sulfur dioxide-nitric acid mixtures, Phys. Chem. Chem. Phys., 9, 3432-3439, 2007.

Prospero, J. M.: Long-term measurements of the transport of African mineral dust to the southeastern United States: implications for regional air quality, J. Geophys. Res.-Atmos., 104, 15917-15927, 1999.

Rattigan, O. V., Boniface, J., Swartz, E., Davidovits, P., Jayne, J. T., Kolb, C. E., and Worsnop, D. R.: Uptake of gas-phase SO, in aqueous sulfuric acid: oxidation by $\mathrm{H}_{2} \mathrm{O}_{2}, \mathrm{O}_{3}$, and $\mathrm{HONO}, \mathrm{J}$. Geophys. Res.-Atmos., 105, 29065-29078, 2000.

Ridgwell, A. and Zeebe, R. E.: The role of the global carbonate cycle in the regulation and evolution of the Earth system, Earth Planet. Sci. Lett., 234, 299-315, 2005.

Rossi, M. J.: Heterogeneous reactions on salts, Chem. Rev., 103, 4823-4882, 2003.

Rubasinghege, G., Lentz, R. W., Scherer, M. M., and Grassian, V. H.: Simulated atmospheric processing of iron oxyhydroxide minerals at low $\mathrm{pH}$ : Roles of particle size and acid anion in iron dissolution, Proc. Natl. Acad. Sci. U. S. A., 107, 6628-6633, 2010.

Samuels, A. C., Zhu, C. J., Williams, B. R., Ben-David, A., Miles, R. W., and Hulet, M.: Improving the linearity of infrared diffuse reflection spectroscopy data for quantitative analysis: An application in quantifying organophosphorus contamination in soil, Anal. Chem., 78, 408-415, 2006.

Seinfeld, J. H., Pandis, S. N.: Atmospheric Chemistry and Physics: From Air Pollution to Climate Change, John Wiley \& Sons, 1998.

Shaka, H., Robertson, W. H., and Finlayson-Pitts, B. J.: A new approach to studying aqueous reactions using diffuse reflectance infrared Fourier transform spectrometry: application to the uptake and oxidation of $\mathrm{SO}_{2}$ on $\mathrm{OH}$-processed model sea salt aerosol, Phys. Chem. Chem. Phys., 9, 1980-1990, 2007.

Shaw, R. W. and Paur, R. J.: Measurements of sulfur in gases and particles during 16 months in the Ohio river valley, Atmos. Environ., 17, 1431-1438, 1983.

Smith, I. W. M.: Laboratory studies of atmospheric reactions at low temperatures, Chem. Rev., 103, 4549-4564, 2003.

Smith, R. M. and Martell A. E.: Critical Stability Contants, Plenum, New York, 1982.

Song, C. H. and Carmichael, G. R.: The aging process of naturally emitted aerosol (sea-salt and mineral aerosol) during long range transport, Atmos. Environ., 33, 2203-2218, 1999.

Srivastava, R. K. and Jozewicz, W.: Flue gas desulfurization: The state of the art, J. Air Waste Manage. Assoc., 51, 1676-1688, 2001.

Steger, E. and Schmidt, W.: Infrarotspektren von sulfaten und phosphaten, Berichte Der Bunsen-Gesellschaft Fur Physikalische Chemie, 68, 102-109, 1964.

Tabazadeh, A., Jacobson, M. Z., Singh, H. B., Toon, O. B., Lin, J. S., Chatfield, R. B., Thakur, A. N., Talbot, R. W., and Dibb, J. E.: Nitric acid scavenging by mineral and biomass burning aerosols, Geophys. Res. Lett., 25, 4185-4188, 1998.

Talbot, R. W., Dibb, J. E., and Loomis, M. B.: Influence of vertical transport on free tropospheric aerosols over the central USA in springtime, Geophys. Res. Lett., 25, 1367-1370, 1998.

Thompson, M. M. and Palmer, R. A.: In Situ Fourier Transform Infrared Diffuse Reflectance and Photoacoustic Spectroscopy characterization of Sulfur-Oxygen species resulting from the reaction of $\mathrm{SO}_{2}$ with $\mathrm{CaCO}_{3}$, Appl. Spectrosc., 42, 945-951, 1988.

Tong, S. R., Wu, L. Y., Ge, M. F., Wang, W. G., and Pu, Z. F.: Heterogeneous chemistry of monocarboxylic acids on alpha- $\mathrm{Al}_{2} \mathrm{O}_{3}$ at different relative humidities, Atmos. Chem. Phys., 10, 75617574, doi:10.5194/acp-10-7561-2010, 2010.

Ullerstam, M., Vogt, R., Langer, S., and Ljungstrom, E.: The kinetics and mechanism of $\mathrm{SO}_{2}$ oxidation by $\mathrm{O}_{3}$ on mineral dust, Phys. Chem. Chem. Phys., 4, 4694-4699, 2002.

Usher, C. R. and Grassian, V. H.: Knudsen cell study of $\mathrm{SO}_{2}$ reactivity on mineral oxide powders, Abstracts of Papers of the American Chemical Society, 222, 211-PHYS, 2001.

Usher, C. R., Al-Hosney, H., Carlos-Cuellar, S., and Grassian, V. H.: A laboratory study of the heterogeneous uptake and oxidation of sulfur dioxide on mineral dust particles, J. Geophys. Res.Atmos., 107, 4713, doi:10.1029/2002JD002051, 2002.

Usher, C. R., Michel, A. E., and Grassian, V. H.: Reactions on mineral dust, Chem. Rev., 103, 4883-4939, 2003.

Vogt, R. and Finlayson-Pitts, B. J.: A Diffuse-Reflectance Infrared 
Fourier-Transform spectroscopic (DRIFTS) study of the surfacereaction of $\mathrm{NaCl}$ with gaseous $\mathrm{NO}_{2}$ and $\mathrm{HNO}_{3}$, J. Phys. Chem., 98, 3747-3755, 1994.

Wagner, C., Hanisch, F., Holmes, N., de Coninck, H., Schuster, G., and Crowley, J. N.: The interaction of $\mathrm{N}_{2} \mathrm{O}_{5}$ with mineral dust: aerosol flow tube and Knudsen reactor studies, Atmos. Chem. Phys., 8, 91-109, doi:10.5194/acp-8-91-2008, 2008.

Xiao, H., Carmichael, G. R., Durchenwald, J., Thornton, D., and Bandy, A.: Long-range transport of $\mathrm{SO}_{\mathrm{x}}$ and dust in East Asia during the PEM B Experiment, J. Geophys. Res.-Atmos., 102, 28589-28612, 1997.

Zhang, D. Z., Shi, G. Y., Iwasaka, Y., and Hu, M.: Mixture of sulfate and nitrate in coastal atmospheric aerosols: individual particle studies in Qingdao (36 degrees 04 ' N, 120 degrees 21' E), China, Atmos. Environ., 34, 2669-2679, 2000.
Zhang, X. Y., Zhuang, G. S., Chen, J. M., Wang, Y., Wang, X., An, Z. S., and Zhang, P.: Heterogeneous reactions of sulfur dioxide on typical mineral particles, J. Phys. Chem. B, 110, 12588 12596, 2006.

Zhang, Y. and Carmichael, G. R.: The role of mineral aerosol in tropospheric chemistry in East Asia - A model study, J. Appl. Meteorol., 38, 353-366, 1999.

Zhuang, G. S., Yi, Z., Duce, R. A., and Brown, P. R.: Link between iron and sulfur cycles suggested by detection of $\mathrm{Fe}(\mathrm{II})$ in remote marine aerosols, Nature, 355, 537-539, 1992.

Zhuang, H., Chan, C. K., Fang, M., and Wexler, A. S.: Formation of nitrate and non-sea-salt sulfate on coarse particles, Atmos. Environ., 33, 4223-4233, 1999. 